\title{
1 Emergence of SARS-CoV-2 Resistance with Monoclonal Antibody Therapy
}

3 Manish C. Choudhary ${ }^{*}$, Kara W. Chew ${ }^{2 *}$, Rinki Deo ${ }^{1}$, James P. Flynn ${ }^{1}$, James Regan ${ }^{1}$, Charles R.

4 Crain ${ }^{1}$, Carlee Moser ${ }^{3}$, Michael Hughes ${ }^{3}$, Justin Ritz ${ }^{3}$, Ruy M. Ribeiro ${ }^{4}$, Ruian $\mathrm{Ke}^{4}$, Joan A.

5 Dragavon $^{5}$, Arzhang C. Javan ${ }^{6}$, Ajay Nirula ${ }^{7}$, Paul Klekotka ${ }^{7}$, Alexander L. Greninger ${ }^{5}$, Courtney

6 V. Fletcher ${ }^{8}$, Eric S. Daar ${ }^{2}$, David A. Wohl ${ }^{9}$, Joseph J. Eron ${ }^{9}$, Judith S. Currier ${ }^{2}$, Urvi M. Parikh ${ }^{10}$,

7 Scott F. Sieg ${ }^{11}$, Alan S. Perelson ${ }^{4}$, Robert W. Coombs ${ }^{5}$, Davey M. Smith ${ }^{12^{*}}$, and Jonathan Z. Li ${ }^{1 *}$

8 for the ACTIV-2/A5401 Study Team

10 1. Brigham and Women's Hospital, Harvard Medical School, Boston, MA

112 2. University of California, Los Angeles, Los Angeles, CA

12 3. Harvard T.H. Chan School of Public Health, Boston, MA

13 4. Los Alamos National Laboratory, Los Alamos, NM

14 5. University of Washington, Seattle, WA

15 6. National Institutes of Health, Bethesda, MD

16 7. Lilly Research Laboratories, San Diego, CA

17 8. University of Nebraska Medical Center, Omaha, NE

189 9. University of North Carolina, Chapel Hill, NC

19 10. University of Pittsburgh, Pittsburgh, PA

20 11. Case Western Reserve University, Cleveland, $\mathrm{OH}$

21 12. University of California, San Diego, San Diego, CA

$23 *$ Contributed equally to this article 
26 Corresponding Authors:

27 Jonathan Li, MD

28 Brigham and Women's Hospital

29 Harvard Medical School

30 jli@bwh.harvard.edu

32 Davey Smith, MD

33 University of California, San Diego

34 davey@ucsd.edu

37 Keywords: COVID-19 treatment, SARS-CoV-2 escape, drug resistance, monoclonal antibody

\section{Financial support:}

40 This study was supported by the National Institute of Allergy and Infectious Diseases; ACTIV-

41 2/A5401 ClinicalTrials.gov number NCT04518410. Portions of this work were performed under

42 the auspices of the U.S. Department of Energy through Los Alamos National Laboratory

43 (LANL), which is operated by Triad National Security, LLC for the National Nuclear Security

44 Administration of the U.S. Department of Energy (contract No. 89233218CNA000001). The

45 work was also supported by LANL's Laboratory Directed Research and Development program

46 (projects No. 20200743ER, 20200695ER, and 20210730ER), by NIH grants R01-AI028433, 
47 R01-OD011095 (ASP), R01-AI15270301 (RK) and R01-AI116868 (RMR), by the Defense

48 Advanced Research Projects Agency (contract No. HR0011938513) and by the DOE Office of

49 Science through the National Virtual Biotechnology Laboratory, a consortium of DOE National

50 Laboratories focused on response to COVID-19, with funding provided by the Coronavirus

51 CARES Act.

52

\section{Disclosures:}

54 KWC has received research funding to the institution from Merck Sharpe \& Dohme. PK and AN

55 are employees and shareholders of Eli Lilly. ALG reports contract testing from Abbott and

56 research support from Merck and Gilead. ESD has consulted for Gilead, Merck and ViiV and

57 received research support from Gilead and ViiV. ASP has consulted for Amphylx Pharmaceticals.

58 DMS has consulted for Bayer Pharmaceuticals, Linear Therapies, Matrix Biomed, FluxErgy and

59 Brio Clinical. JZL has consulted for Abbvie.

60 
medRxiv preprint doi: https://doi.org/10.1101/2021.09.03.21263105; this version posted September 15, 2021. The copyright holder for this preprint (which was not certified by peer review) is the author/funder, who has granted medRxiv a license to display the preprint in perpetuity. All rights reserved. No reuse allowed without permission.

\section{ABSTRACT}

62 Resistance mutations to monoclonal antibody (mAb) therapy has been reported, but in the non-

63 immunosuppressed population, it is unclear if in vivo emergence of SARS-CoV-2 resistance

64 mutations alters either viral replication dynamics or therapeutic efficacy. In ACTIV-2/A5401, non-

65 hospitalized participants with symptomatic SARS-CoV-2 infection were randomized to

66 bamlanivimab (700mg or $7000 \mathrm{mg})$ or placebo. Treatment-emergent resistance mutations were

67 significantly more likely detected after bamlanivimab 700mg treatment than placebo (7\% of 111

68 vs $0 \%$ of 112 participants, $\mathrm{P}=0.003$ ). There were no treatment-emergent resistance mutations

69 among the 48 participants who received bamlanivimab 7000mg. Participants with emerging mAb

70 resistant virus had significantly higher pre-treatment nasopharyngeal and anterior nasal viral load.

71 Intensive respiratory tract viral sampling revealed the dynamic nature of SARS-CoV-2 evolution,

72 with evidence of rapid and sustained viral rebound after emergence of resistance mutations, and

73 worsened symptom severity. Participants with emerging bamlanivimab resistance often

74 accumulated additional polymorphisms found in current variants of concern/interest and

75 associated with immune escape. These results highlight the potential for rapid emergence of

76 resistance during $\mathrm{mAb}$ monotherapy treatment, resulting in prolonged high level respiratory tract

77 viral loads and clinical worsening. Careful virologic assessment should be prioritized during the

78 development and clinical implementation of antiviral treatments for COVID-19. 
medRxiv preprint doi: https://doi.org/10.1101/2021.09.03.21263105; this version posted September 15, 2021. The copyright holder for this

\section{INTRODUCTION}

81 Across a broad spectrum of viral infections, host immune pressure ${ }^{1,2}$ and antiviral therapy ${ }^{3-5}$ can $^{-1}$

82 select for viral escape mutations. The detection and characterization of antiviral resistance

83 mutations has been critical for the selection of appropriate antiviral therapies and to advance our

84 understanding of viral adaptation against evolutionary pressures ${ }^{6}$. Monoclonal antibody (mAb)

85 therapy is the current treatment of choice for non-hospitalized persons with early SARS-CoV-2

86 infections and mild to moderate COVID-19 ${ }^{7,8}$. Bamlanivimab was the first mAb to receive FDA

87 emergency use authorization (EUA) after it was demonstrated that treatment with bamlanivimab

88 decreased nasopharyngeal (NP) SARS-CoV-2 detection and the risk of hospitalization or death

89 when compared to placebo ${ }^{9}$. The emergence of SARS-CoV-2 sequence changes was reported

90 shortly after the introduction of $\mathrm{mAbs}^{7,10,11}$, but there has not been definitive evidence that the

91 emergence of SARS-CoV-2 resistance mutations can lead to altered in vivo intrahost viral

92 replication dynamics and loss of therapeutic efficacy.

ACTIV-2/A5401 is a platform trial to evaluate efficacy of antiviral agents to prevent

94 disease progression in non-hospitalized persons with symptomatic SARS-CoV-2 infection

95 (NCT04518410). Participants were randomized to receive either bamlanivimab or placebo, with

96 frequent NP swab and daily anterior nasal (AN) swab collection. We utilized quantitative viral

97 load testing and Spike (S) gene next-generation sequencing to assess the emergence of viral

98 resistance mutations to bamlanivimab and their impact on viral load dynamics. These results

99 provide a window into the dynamic nature of SARS-CoV-2 intrahost viral population shifts and

100 demonstrate for the first time that in non-immunosuppressed persons, the emergence of viral

101 resistance can alter viral decay kinetics and lead to loss of antiviral activity. 
medRxiv preprint doi: https://doi.org/10.1101/2021.09.03.21263105; this version posted September 15, 2021. The copyright holder for this preprint (which was not certified by peer review) is the author/funder, who has granted medRxiv a license to display the preprint in perpetuity.

\section{RESULTS}

104 SARS-CoV-2 resistance mutations emerging with mAb treatment were associated with 105 changes in viral replication kinetics. A total of 94 participants were enrolled in the $7000 \mathrm{mg}$ 106 cohort (48 in the treatment arm and 46 in the placebo arm, enrolled between August 2020 and 107 October 2020) and 223 participants were enrolled in the ACTIV-2/A5401 phase 2 bamlanivimab $108700 \mathrm{mg}$ cohort (111 in the treatment and 112 in placebo arms, enrolled between October 2020 and 109 November 2020). The 7000mg dosing group was halted early due to the results of the BLAZE-1 110 study showing similar virologic efficacy between the bamlanivimab $7000 \mathrm{mg}$ and $700 \mathrm{mg}$ groups ${ }^{9}$.

111 Viral sequences were successfully obtained from 207 participants in the $700 \mathrm{mg}$ bamlanivimab

112 study and 78 in the $7000 \mathrm{mg}$ study from at least 1 respiratory sample with quantitative SARS-CoV-

1132 measurement $\geq 2 \log _{10}$ RNA copies/mL at baseline or during 28 days of follow-up. Primary 114 resistance mutations (L452R, E484K, E484Q, F490S and S494P) $)^{7,12}$ at $\geq 20 \%$ frequency were not

115 detected in any participants in the 7000mg bamlanivimab study, either at baseline or following the 116 single infusion. In the 700mg bamlanivimab arm, three participants had primary resistance 117 mutations at baseline (one L452R in the setting of B.1.427/429/Epsilon variant infection and two 118 participants with E484K) while the placebo arm had two cases of resistance mutations present at 119 baseline (both L452R in the setting of Epsilon infection, Figure 1). Treatment-emergent mutations 120 at $\geq 20 \%$ frequency (not detected at baseline) were significantly more likely to be detected after 121 bamlanivimab $700 \mathrm{mg}$ treatment than placebo ( $7 \%$ vs $0 \%, \mathrm{P}=0.003)$; E484K was found in 5 of 8 122 cases of emergent resistance, E484Q in two cases, and S494P in one case (Figure 1b). There were 123 two cases of emerging resistance mutations present only as low frequency variants $(<20 \%$ 124 frequency): one participant in the placebo arm had an emergent F490S mutation (participant B2_9, 
medRxiv preprint doi: https://doi.org/10.1101/2021.09.03.21263105; this version posted September 15, 2021. The copyright holder for this preprint (which was not certified by peer review) is the author/funder, who has granted medRxiv a license to display the preprint in perpetuity. All rights reserved. No reuse allowed without permission.

125 Supplemental Figure 1), while one participant in the bamlanivimab 700mg treatment arm had emerging S494P concurrent with an emerging E484K (participant B2_6, Supplemental Figure 1).

Quantitative SARS-CoV-2 viral loads were measured from NP swabs at days 0, 3, 7, 14,

12821 and 28 of the trial, and from AN swabs daily at each of the first 14 days and at days 21 and 28.

129 We assessed differences in viral loads in those receiving bamlanivimab $700 \mathrm{mg}$ treatment by the 130 presence of emerging resistance. Pre-treatment NP and AN swab viral loads were higher for 131 participants with emerging resistance mutations compared to those with no mutations (emerging 132 vs no mutation viral loads at day 0 , NP swab: median 7.6 vs $5.5 \log _{10}$ copies $/ \mathrm{mL}, \mathrm{P}=0.04 ; \mathrm{AN}$ 133 swab: median 6.6 vs $4.3 \log _{10}$ copies $/ \mathrm{mL}, \mathrm{P}=0.02$, Table 1$)$. Those with emerging resistance also 134 had persistently elevated NP and AN viral loads throughout the first 14 days after study enrollment 135 (Figure 2). Individuals with emerging resistance were older (emerging vs no mutation: median age 13656 vs 45 years, $\mathrm{P}=0.01$ ) and while not statistically significant, the median duration of symptoms at 137 study entry was modestly shorter in those with emerging resistance compared to those without any 138 mutations (emerging vs no mutations: median 4.5 vs 6.0 days, Table 1). Six of the participants 139 with emerging resistance had samples available for baseline serologies and all were negative for

140 IgG (Supplemental Figure 2). Measurements of bamlanivimab serum concentrations in 141 participants with emerging resistance showed results generally concordant with expected values

142 for the $700 \mathrm{mg}$ dose, including for maximal concentrations (Cmax) at the end of infusion and 143 concentrations at day 28 (Supplemental Table 1) ${ }^{13}$. One participant (B2_6) did have a serum 144 concentration at day 28 below the limit of quantitation and an elimination half-life faster than 145 typical. 
medRxiv preprint doi: https://doi.org/10.1101/2021.09.03.21263105; this version posted September 15, 2021. The copyright holder for this preprint (which was not certified by peer review) is the author/funder, who has granted medRxiv a license to display the preprint in perpetuity. All rights reserved. No reuse allowed without permission.

147 Evidence of dynamic SARS-CoV-2 viral population shifts and differential viral fitness after

148 mAb treatment. We observed that the emergence of SARS-CoV-2 resistance mutations was

149 closely associated with a relatively consistent change in viral load kinetics. This is exemplified in

150 Figure 3 with two examples of viral rebound in participants with emergence of escape variants. In

151 case B2_3, intensive $\mathrm{S}$ gene sequencing of virus isolated from the AN swabs revealed the

152 emergence of the E484K resistance mutation on study day 3 as a low frequency variant that rapidly

153 took over as the majority population by the next day (Figure 3A, lower panel) and was associated

154 with a $3.6 \log _{10}$ increase in AN swab viral loads over the subsequent 4 days to a peak of $7.8 \log _{10}$

155 copies/mL on study day 7 before declining. For B2_2, the participant had evidence of baseline

156 E484K mutation and low-frequency E484Q in the NP swab (Figure 3B). The AN swab showed

157 low frequency E484K and Q mutations. After bamlanivimab treatment, there were rapid, dynamic

158 shifts in the viral population in the AN swab sample including both the E484K and Q mutations,

159 with the viral load peaking at $6.8 \log _{10}$ copies/mL over 8 days concurrent with E484Q becoming

160 the dominant mutation. Among the 8 participants with emerging resistance, the median AN swab

161 viral load increase was 3.3 (range 0.3 - 5.2) $\log _{10}$ RNA copies/mL over a median of 4.5 days

162 (Supplemental Figure 1) and this viral rebound is highlighted in the comparison of median viral

163 loads between those with and without emerging resistance mutations (Figure 2).

164 To quantify the replicative fitness of the different strains, we developed a mathematical

165 model and fit it to both viral load data and variant frequency data collected from 6 participants in

166 the treatment arm with either E484K or Q resistance emergence. In this model, we assumed that

167 each variant is initially present and grows or declines exponentially at a constant rate (see Methods)

168 as was consistent with the data (Supplemental Figure 3). We chose the first 8-13 time points for

169 model fitting covering the emergence of the resistance mutations but prior to the eventual viral 
medRxiv preprint doi: https://doi.org/10.1101/2021.09.03.21263105; this version posted September 15, 2021. The copyright holder for this

170 load declines. We estimated both the initial viral load and the rate of exponential increase or

171 decrease for each variant. From the estimation across the 6 individuals, the wild-type amino acid

172 (i.e., 484E), always declined under treatment, with the exponential rate varying from -0.2 to -3.2

173 per day (Supplemental Table 2). In contrast, the mutant 484K always increased under mAb

174 treatment, confirming it was a resistant mutant, with an exponential growth rate that varied over a

175 wide range (0.5 to 2.3 per day, Supplemental Figure 3G). The 484Q mutant was found in two 176 participants, including low-frequency E484K and Q present at baseline in the AN swab sample of

177 participant B2_2. We estimated that virus harboring 484Q was more fit than 484K in the setting 178 of antibody treatment and grew at approximately twice the rate of the $484 \mathrm{~K}$ variant (Supplemental

179 Table 2). In participant B2_5, viral loads in the setting of the 484Q mutant declined, but with a 180 rate much slower than the wildtype 484E, suggesting that it is more fit than 484E in the presence 181 of the mAb or developing host immune responses.

183 Emergence of additional Spike polymorphisms. In those with emerging bamlanivimab

184 resistance, we next assessed the emergence of additional S gene sequence changes outside of the 185 primary sites of resistance (L452R, E484K, E484Q, F490S and S494P). We found that emergence 186 of additional polymorphisms was common and could be detected in all participants with either 187 baseline or emerging bamlanivimab primary resistance mutations, although most were present at 188 low-frequencies (Figure 4). One emergent polymorphism, Q493R, was detected in B2_7 and has 189 been described as a potential bamlanivimab resistance site $^{10}$. Interestingly, a number of 190 polymorphisms were detected at sites distinct from the bamlanivimab site of activity and likely 191 reflect escape from host immune pressures. For example, deletions at amino acid positions 141192143 were detected to emerge in both participants B2_2 and B2_4. These N-terminal domain (NTD) 
medRxiv preprint doi: https://doi.org/10.1101/2021.09.03.21263105; this version posted September 15, 2021. The copyright holder for this preprint (which was not certified by peer review) is the author/funder, who has granted medRxiv a license to display the preprint in perpetuity. All rights reserved. No reuse allowed without permission.

193 deletions have previously been described in immunosuppressed participants with immune escape

194 and persistent COVID-19 $9^{14,15}$. These deletions have also been detected in the wider pandemic and

195 represent a common site of viral escape against antibody pressure on the $\mathrm{NTD}^{16}$. A number of 196 emerging polymorphisms were also detected that are also in several variants of concern and 197 postulated to be involved in either immune escape or enhanced receptor binding. These include 198 L5F (PID B2_2, also in B.1.526/Iota), P9L (PID B2_2, also in C.1.2), L18F (PID B2_8, also in 199 B.1.351/Beta, P.1/Gamma), D138Y (in P.1/Gamma), N501Y (ACE-2 binding domain mutation in 200 PID B2_10, also in B.1.1.7/Alpha, B.1.351/Beta, P.1/Gamma), and P681H (furin cleavage site 201 mutation in PID B2_10, also in B.1.1.7/Alpha) $)^{17,18}$.

202 We used day 7 NP swab sequencing results to compare the rate of polymorphism 203 emergence across the participant groups as AN swab sequencing was performed only for 204 participants with evidence of resistance emergence. We detected no significant differences in the 205 number of emerging polymorphisms between those with emerging resistance, treated participants 206 without resistance and participants who received placebo (Supplemental Figure 4).

208 Viral rebound during after bamlanivimab resistance emergence is associated with

209 worsened symptoms. To assess the clinical impact of the viral load resurgence seen in those

210 with emerging bamlanivimab resistance mutations, we compared longitudinal symptom scores

211 for bamlanivimab-treated participants with and without emerging resistance mutations. Total

212 symptom scores were calculated based on a 28 day diary completed by the participants for 13

213 targeted symptoms ${ }^{19}$. On an individual-level, higher symptom scores were frequently detected

214 after the emergence of resistance and increase in respiratory tract viral loads (Figure 5A). In the 215 population analysis, there was no significant differences in symptom scores between groups 
medRxiv preprint doi: https://doi.org/10.1101/2021.09.03.21263105; this version posted September 15, 2021. The copyright holder for this preprint (which was not certified by peer review) is the author/funder, who has granted medRxiv a license to display the preprint in perpetuity. All rights reserved. No reuse allowed without permission.

216 before the emergence of resistance mutations. In participants of the bamlanivimab 700mg

217 treatment arm with emerging resistance mutations, median AN viral load increase began at the

218 time of resistance detection, with significantly higher subsequent viral loads and total symptom

219 scores compared to those in the treatment arm without resistance (Figure 5B). 
medRxiv preprint doi: https://doi.org/10.1101/2021.09.03.21263105; this version posted September 15, 2021. The copyright holder for this preprint (which was not certified by peer review) is the author/funder, who has granted medRxiv a license to display the preprint in perpetuity. All rights reserved. No reuse allowed without permission.

\section{DISCUSSION}

221 In this virologic analysis of a randomized placebo-controlled clinical trial of non-hospitalized

222 persons with early COVID-19, we report the emergence of resistance mutations to the mAb

223 bamlanivimab and the effects of these mutations on viral decay and clinical symptoms. These

224 results represent the clearest evidence to date of several key principles: 1) the dynamic nature of

225 SARS-CoV-2 evolution and replication during mAb treatment, 2) treatment-emergent SARS-

$226 \mathrm{CoV}-2$ resistance mutations alter viral replication kinetics and extend the period of high viral loads,

227 3) drug resistance mutations can adversely affect both the virologic and clinical efficacy of a

228 COVID-19 antiviral medication, and 4) the emergence of resistance with mAb treatment is

229 dependent on the treatment dose.

230 In immunocompromised persons with COVID-19, viral evolution can lead to immune

231 escape and rapid emergence against even combination $\mathrm{mAb}$ therapy ${ }^{11,15,20,21}$. Whether these

232 findings are generalizable to the immunocompetent population has been unclear and there has not

233 been definitive evidence that the emergence of SARS-CoV-2 escape mutations impacts in vivo

234 viral replication dynamics and loss of therapeutic efficacy. In this study of bamlanivimab in a

235 general population of outpatients with mild to moderate COVID-19, we show that resistance

236 mutations to monoclonal antibody treatment can emerge quickly and are associated with rapid and

237 sustained increase in respiratory tract SARS-CoV-2 viral load. Importantly, this increase in viral

238 load was followed by significantly worsened clinical symptoms over the subsequent days. These

239 results are consistent with previous reports that during acute SARS-CoV-2 infection, high-level

240 respiratory tract viral loads often precede symptom onset by $1-2$ days $^{22}$.

241 We were able to identify several potential factors that may increase or decrease the risk of

$242 \mathrm{mAb}$ resistance. We found that older age and higher baseline respiratory tract viral load were 
medRxiv preprint doi: https://doi.org/10.1101/2021.09.03.21263105; this version posted September 15, 2021. The copyright holder for this

243 associated with higher risk of resistance emergence, while none of the 48 participants treated with

244 the higher dose bamlanivimab 7000mg therapy developed resistance. Studies of mAb treatments

245 have suggested that earlier initiation of therapy during periods of high respiratory tract viral load

246 is associated with a greater virologic response and likely improved therapeutic efficacy ${ }^{23}$. Our data

247 suggest that mAb treatment during periods of high-level viral loads may come at the cost of

248 increased risk of resistance emergence, although this effect may be mitigated by using higher doses

249 of mAbs. Interestingly, we also noted frequent increase in viral loads associated with resistance

250 emergence that lasted several days to more than a week before declining. Such prolonged rise in

251 viral loads is unusual, especially as these individuals had a median of 5 days of symptoms by the

252 time of study entry and it's expected that levels of respiratory viral loads should already be

253 declining ${ }^{24}$. While the exact cause is unclear, this finding raises several intriguing possibilities.

254 First, antiviral mAb therapies may have host immune modulating effects beyond their capacity to

255 bind and neutralize viral particles ${ }^{25}$. It is unknown whether mAb therapeutics may in some cases

256 interfere with host immune responses, especially in the setting of mAb resistance, leading to

257 suboptimal viral control. Alternatively, there have also been reports from in vitro studies that

258 certain SARS-CoV-2-specific antibodies may lead to antibody-dependent enhancement of

259 infection through an Fc $\gamma$ receptor-dependent mechanism ${ }^{26}$, particularly at sub-neutralizing

260 concentrations, although in vivo confirmation has been challenging to obtain.

261 Our study also found that SARS-CoV-2 populations can turn over quickly, allowing for

262 quick selection of drug resistance associated mutations. In fact, viral populations were found to be

263 able to completely shift from fully sensitive to fully resistant viruses within 24 hours. The emerging

264 primary resistance mutations (e.g., E484K/Q) described in this report not only confer resistance to

$265 \mathrm{mAb}$ therapy but can also lead to decreased efficacy of vaccine-induced immune responses ${ }^{27}$. 
medRxiv preprint doi: https://doi.org/10.1101/2021.09.03.21263105; this version posted September 15, 2021. The copyright holder for this preprint (which was not certified by peer review) is the author/funder, who has granted medRxiv a license to display the preprint in perpetuity. All rights reserved. No reuse allowed without permission.

While the rate of total polymorphism accumulation did not appear to be higher in those who developed bamlanivimab resistance, many of the emerging polymorphisms are also key mutations found in several variants of concern/interest (VOC/VOIs, including B.1.1.7/Alpha, B.1.351/Beta and P.1/Gamma), which are associated with increased transmission efficiency and enhanced outbreaks $^{28}$. The impact of treatment-induced resistance mutations on the spread of these key escape mutations should be further assessed. agent. These results, though, provide important proof of principle for the role that drug resistance

274 may have on virologic and clinical efficacy of SARS-CoV-2 antiviral therapies. These lessons 275 have implications for the development of novel COVID-19 antiviral therapies and have continued 276 relevance for other clinically-approved single agent monoclonal antibody treatments ${ }^{29}$ and for 277 combination therapies where one agent may be ineffective due to circulating variants ${ }^{13}$. Another 278 limitation of this study is the limited sample size of this phase 2 study, especially in the 279 bamlanivimab 7000mg cohort. While treatment-emergent mutations were not found in ACTIV-2 280 participants receiving the higher $7000 \mathrm{mg}$ dose of bamlanivimab, they were frequently detected in 281 the larger BLAZE-1 phase 2 trial of the $7000 \mathrm{mg}^{\text {dose }}{ }^{7}$. One difference between these studies was 282 the longer duration since symptom onset for the ACTIV-2 participants, who enrolled a median of 2836 days since symptom onset versus 4 days for the BLAZE-1 participants. This likely led to higher 284 pretreatment viral loads, which we found to be a risk factor for resistance emergence. 285 Unfortunately, baseline viral loads could not be compared between studies as the BLAZE-1 study 286 did not use a quantitative SARS-CoV-2 viral load assay. These disparate results highlight the 287 importance of incorporating quantitative viral load testing and resistance testing for COVID-19 288 treatment trials of mAbs and other antiviral agents. 
290 SARS-CoV-2 resistance, leading to dramatic viral rebound and worsened symptom severity. While

291 initiation of mAb treatment during early infection is recommended for optimal therapeutic benefit,

292 our results suggest that emerging resistance is a potential risk with treatment during periods of

293 high level viral replication. These findings have implications for the design and utilization of

294 SARS-CoV-2 antiviral therapeutics and provide insights into the prevention of SARS-CoV-2

295 resistance. Careful virologic and pharmacologic assessment of new treatments for COVID-19

296 should be prioritized. 
medRxiv preprint doi: https://doi.org/10.1101/2021.09.03.21263105; this version posted September 15, 2021. The copyright holder for this preprint (which was not certified by peer review) is the author/funder, who has granted medRxiv a license to display the preprint in perpetuity.

\section{METHODS}

\section{Study participants and sample collection}

300 The study participants were enrolled in the ACTIV-2/AIDS Clinical Trials Group (ACTG) A5401

301 phase 2 randomized, placebo-controlled trial of bamlanivimab 7000mg and 700mg mAb therapy.

302 Symptomatic adults $\geq 18$ years of age with a documented positive SARS-CoV-2 antigen or nucleic

303 acid test were enrolled if the diagnostic sample was collected $\leq 7$ days prior to study entry and

304 within 10 days of symptom onset. The $7000 \mathrm{mg}$ dosing group was halted early due to the results of

305 the BLAZE-1 study showing similar virologic efficacy between the bamlanivimab 7000mg and

$306700 \mathrm{mg}_{\text {groups }}{ }^{9}$. A total of 95 participants were randomized in the bamlanivimab $7000 \mathrm{mg}$ study

307 and 222 participants were randomized in the $700 \mathrm{mg}$ study and received an intervention (one

308 bamlanivimab or placebo intravenous infusion). All participants provided written informed

309 consent. Nasopharyngeal (NP) swab samples were collected by research staff at study days 0,3 ,

3107,14 and 28, while anterior nasal (AN) swabs were self-collected by participants daily through

311 study day 14 and at days 21 and 28. Swabs were placed in $3 \mathrm{ml}$ of media (RPMI with 2\% FBS).

312 Total symptom scores were calculated based on a 28 day diary completed by the

313 participants for 13 targeted symptoms ${ }^{19}$. The targeted symptoms are feeling feverish, cough,

314 shortness of breath or difficulty breathing, sore throat, body pain or muscle pain or aches, fatigue,

315 headache, chills, nasal obstruction or congestion, nasal discharge, nausea, vomiting, and diarrhea.

316 Each symptom is scored daily by the participant as absent (score 0), mild (1) moderate (2) and

317 severe (3). 
medRxiv preprint doi: https://doi.org/10.1101/2021.09.03.21263105; this version posted September 15, 2021. The copyright holder for this preprint (which was not certified by peer review) is the author/funder, who has granted medRxiv a license to display the preprint in perpetuity. All rights reserved. No reuse allowed without permission.

SARS-CoV-2 viral load from NP and AN swab samples were quantified using the Abbott m2000 system. SARS-CoV-2 quantitative Laboratory Developed Test (LDT) was developed utilizing

322 open mode functionality on $m 2000 s p / r t$ (Abbott, Chicago, IL) by using EUA Abbott SARS-CoV-

3232 qualitative reagents ${ }^{30}$. Identical extraction and amplification protocols developed for RealTime

324 SARS-CoV-2 qualitative EUA assay were also used for the development of the RealTime SARS-

325 CoV-2 quantitative LDT ${ }^{31}$. In this assay, 2 calibrator levels $\left(3 \log _{10}\right.$ RNA copies $/ \mathrm{mL}$ and $6 \log _{10}$

326 RNA copies $/ \mathrm{mL}$ ) tested in triplicate were used to generate a calibration curve and 3 control levels

327 (negative, low positive at $3 \log _{10}$ RNA copies/mL and high positive at $5 \log _{10}$ RNA copies/mL)

328 were included in each run for quality management. In addition, batches of a matrix-specific control

329 ("external" swab control) with a target of 200 copies per $\mathrm{mL}$ were prepared and one unit was

330 included in every run. All controls were monitored using Levy-Jennings plots to monitor inter-

331 run precision. Specimens that were greater than $7 \log _{10}$ RNA copies/mL were diluted 1:1000 and

332 rerun to obtain an accurate viral load result. The lower limit of quantification was $2.0 \log _{10}$ SARS-

333 CoV-2 RNA copies/mL.

335 S gene sequencing was performed on NP swab samples at two time points for all participants:

336 baseline (study entry) and the last sample with a viral load (VL) $\geq 2 \log _{10}$ SARS-CoV-2 RNA

337 copies/mL. In participants with evidence of slow viral decay (VL $\geq 2 \log _{10}$ copies/mL at study day

338 14) or viral rebound (increase in NP swab VL), we performed S gene sequencing of all NP swab

339 samples with VL $\geq 2 \log _{10}$ copies/mL. Sequencing of daily AN swab samples was performed for

340 participants with any emerging bamlanivimab resistance mutations detected on NP swab samples.

341 Viral RNA extraction was performed on $1 \mathrm{~mL}$ of swab fluid by use of the TRIzol-LS ${ }^{\mathrm{TM}}$ Reagent

342 (ThermoFisher), as previously described ${ }^{32}$. cDNA synthesis was performed using Superscript IV 
medRxiv preprint doi: https://doi.org/10.1101/2021.09.03.21263105; this version posted September 15, 2021. The copyright holder for this preprint (which was not certified by peer review) is the author/funder, who has granted medRxiv a license to display the preprint in perpetuity. All rights reserved. No reuse allowed without permission.

343 reverse transcriptase (Invitrogen), per the manufacturer's instructions. Spike gene amplification 344 was performed using a nested PCR strategy with in-house designed primer sets targeting codons 345 1-814 of Spike. PCR products were pooled, and Illumina library construction was performed using

346 the Nextera XT Library Prep Kit (Illumina). Sequencing was performed on the Illumina MiSeq

347 platform. Raw sequence data were analyzed using PASeq v1.4 (https://www.paseq.org). Briefly, 348 data were quality filtered using Trimmomatic (v0.30), using a Q25/5 bp sliding window and a 70 349 bp minimum length. Non-viral contamination was filtered out using BBsplit v35.76. Filtered reads

350 were then merged with pear v0.9.6 aligned to the reference sequence using Bowtie2 v2.1.0). 351 Amino acid variants were then called at the codon level using perl code and used for resistance 352 interpretation with a $1 \%$ limit of detection.

\section{Detection of Spike mutations}

355 We assessed the presence of previously confirmed bamlanivimab resistance mutations (L452R, 356 E484K, E484Q, F490S, and S494P) ${ }^{7,12}$. The detection of resistance mutations down to $1 \%$

357 frequency was performed using Paseq ${ }^{33}$. Mutations detected by next-generation sequencing at $<20 \%$ 358 of the viral population were labelled as "low frequency" variants as they would largely be missed 359 by traditional Sanger sequencing. A minimum average of 500x sequencing coverage per sample 360 was required for variant calling.

362 Serology

363 IgG antibodies recognizing SARS-CoV-2 Spike (S), Receptor binding domain (RBD),

364 Nucleocapsid (N) and N terminal domain (NTD) proteins were measured in serum samples using 365 a commercially available multiplex kit (catalog \# K15359U) from Meso Scale Diagnostics (MSD, 
medRxiv preprint doi: https://doi.org/10.1101/2021.09.03.21263105; this version posted September 15, 2021. The copyright holder for this preprint (which was not certified by peer review) is the author/funder, who has granted medRxiv a license to display the preprint in perpetuity. All rights reserved. No reuse allowed without permission.

Rockville, MD). Assays were performed according kit instructions. Briefly, plates were treated with MSD Blocker A to prevent non-specific antibody binding. Serum samples were thawed and diluted 1:500 and 1:5000 in MSD diluent. IgG was detected by incubation with MSD SULFOTAG anti-IgG antibody. Measurements were performed with a MESO Quickplex SQ 120 reader. Three internal serum controls provided by MSD were run with each plate. Pre-pandemic sera from healthy adult donors ( $\mathrm{n}=10$; AMSBIO LLC, Cambridge MA 02141) were included as additional negative controls for the assays. Threshold values for antibody titers (S, RBD and N proteins) were provided by MSD and were based on analyses of 200 pre-2019 and 214 COVID+

374 (PCR-confirmed) COVID-9 patients. The thresholds utilized provide 84\%, 71\% and $71 \%$ sensitivity and $99.5 \%, 98.5 \%$ and $100 \%$ specificity for Spike, RBD and N antibody responses, respectively. NTD thresholds were not available.

Pharmacokinetic analysis.

379 Blood samples for quantitation of bamlanivimab serum concentrations were collected pre-dose 380 and at the following times after the end of infusion: 30 minutes, days 14 and 28 and weeks 12 and

381 24. Pharmacokinetic parameters of interest were maximum concentration (Cmax), elimination 382 half-life and clearance (CL) and were calculated based on the statistical moment theory using the 383 trapezoidal rule and linear regression (WinNonLin, Certara, Princeton, NJ, USA).

\section{Statistical analysis and mathematical modeling}

386 The non-parametric Mann-Whitney U test was used to compare differences in viral loads between

387 groups. Chi-squared tests and Fisher's exact tests were used for analyses of proportions. All 388 statistical analyses were performed in GraphPad Prism (Version 9.1.1). Intensive AN swab viral 
medRxiv preprint doi: https://doi.org/10.1101/2021.09.03.21263105; this version posted September 15, 2021. The copyright holder for this

loads and sequences were used for mathematical modeling. The mutational load was calculated by

390 multiplying resistance mutation frequency by the total viral load. In the model, we assumed that

391 the $i$ th variant, $V_{\mathrm{i}}$, has an initial load $V_{\mathrm{i}, 0}$ and its population size changes exponentially at a constant

392 rate, $r_{\mathrm{i}}$ :

393

$$
V_{i}(t)=V_{i, 0} e^{r_{i} t}
$$

394 Then, the total viral load at time t, $V(t)$ was calculated as:

$$
V(t)=\sum_{i} V_{i, 0} e^{r_{i} t}
$$

396 The model predicted frequency of each variant was

$$
f_{i}(t)=\frac{V_{i, 0} e^{r_{i} t}}{V(t)}
$$

399 We estimated the initial load, $V_{\mathrm{i}, 0}$ and the rate of exponential increase/decrease, $r_{\mathrm{i}}$, from the viral 400 load and viral frequency data fitted simultaneously. Note that in this model, we assumed that the 401 observed mutants were present at the time of antibody infusion or were produced quickly near that 402 time.

404 sum of squares (RSS) between the model predicted viral load and the measured viral load on a 405 logarithmic scale using $\log 10$. The log-scale was used because viral loads were measured using 406 PCR and thus the measurement error was multiplicative, making the logarithm the natural scale to 407 use. We then calculated the RSS between model predicted frequencies and measured frequencies 408 for the mutants. The final RSS was calculated as the sum of the two RSS errors:

$$
R S S=\sum_{k}\left[\left(\log _{10} V\left(t_{k}\right)-\log _{10} Y_{k}\right)^{2}+\sum_{i}\left(f_{i}\left(t_{k}\right)-F_{i, k}\right)^{2}\right]
$$


medRxiv preprint doi: https://doi.org/10.1101/2021.09.03.21263105; this version posted September 15, 2021. The copyright holder for this preprint (which was not certified by peer review) is the author/funder, who has granted medRxiv a license to display the preprint in perpetuity. All rights reserved. No reuse allowed without permission.

410 Where $k$ denotes the $k^{\text {th }}$ time point, $Y_{\mathrm{k}}$ and $F_{\mathrm{i}, \mathrm{k}}$ denote the measured viral load and the measured

411 frequency for the $i^{\text {th }}$ variant at the $k^{\text {th }}$ time point. All data will be available by request to the AIDS

412 Clinical Trials Group and code will be available upon request to the authors.

413 
medRxiv preprint doi: https://doi.org/10.1101/2021.09.03.21263105; this version posted September 15, 2021. The copyright holder for this preprint (which was not certified by peer review) is the author/funder, who has granted medRxiv a license to display the preprint in perpetuity. All rights reserved. No reuse allowed without permission.

\section{Author contributions}

415 MCC, KC, RC, DMS, JZL conceptualized and performed the study, MCC, RD, JPF, JR, CC

416 performed resistance analysis experiment; RMR, RK, ASP performed mathematical modeling; JD,

417 AG performed viral load analysis; UP, SS performed serological analysis; CM, MH, JR performed

418 statistical analysis.

419

420 Acknowledgements

421 We would like to thank the participants, site staff, site investigators, and the entire ACTIV-

422 2/A5401 study team. We thank the PASeq team (Drs. Roger Paredes and Marc Noguera Julian)

423 for their support.

424

425

426 
medRxiv preprint doi: https://doi.org/10.1101/2021.09.03.21263105; this version posted September 15, 2021. The copyright holder for this preprint (which was not certified by peer review) is the author/funder, who has granted medRxiv a license to display the preprint in perpetuity.

\section{References}

4281 Moore, C. B. et al. Evidence of HIV-1 adaptation to HLA-restricted immune responses at a population level. Science 296, 1439-1443 (2002).

4302 Plant, E. P., Manukyan, H., Sanchez, J. L., Laassri, M. \& Ye, Z. Immune Pressure on Polymorphous Influenza B Populations Results in Diverse Hemagglutinin Escape Mutants and Lineage Switching. Vaccines (Basel) 8, doi:10.3390/vaccines8010125 (2020).

4333 Larder, B. A. \& Kemp, S. D. Multiple mutations in HIV-1 reverse transcriptase confer high-level resistance to zidovudine (AZT). Science 246, 1155-1158, doi:10.1126/science.2479983 (1989).

4 Chou, S., Guentzel, S., Michels, K. R., Miner, R. C. \& Drew, W. L. Frequency of UL97 phosphotransferase mutations related to ganciclovir resistance in clinical cytomegalovirus isolates. J Infect Dis 172, 239-242, doi:10.1093/infdis/172.1.239 (1995). Takashita, E. et al. Global update on the susceptibilities of human influenza viruses to neuraminidase inhibitors and the cap-dependent endonuclease inhibitor baloxavir, 20172018. Antiviral Res 175, 104718, doi:10.1016/j.antiviral.2020.104718 (2020).

443

6 Clavel, F. \& Hance, A. J. HIV drug resistance. $N$ Engl J Med 350, 1023-1035, doi:10.1056/NEJMra025195 (2004). Etesevimab on Viral Load in Patients With Mild to Moderate COVID-19: A Randomized Clinical Trial. JAMA 325, 632-644, doi:10.1001/jama.2021.0202 (2021). (EUA) $O F$ CASIRIVIMAB AND IMDEVIMAB, $<$ https://www.fda.gov/media/143892/download $>$ (Accessed July 14, 2021).

9 Chen, P. et al. SARS-CoV-2 Neutralizing Antibody LY-CoV555 in Outpatients with Covid-19. N Engl J Med 384, 229-237, doi:10.1056/NEJMoa2029849 (2021).

10 Starr, T. N., Greaney, A. J., Dingens, A. S. \& Bloom, J. D. Complete map of SARS-CoV2 RBD mutations that escape the monoclonal antibody LY-CoV555 and its cocktail with LY-CoV016. Cell Rep Med 2, 100255, doi:10.1016/j.xcrm.2021.100255 (2021).

Starr, T. N. et al. Prospective mapping of viral mutations that escape antibodies used to treat COVID-19. Science 371, 850-854, doi:10.1126/science.abf9302 (2021). McCallum, M. et al. SARS-CoV-2 immune evasion by the B.1.427/B.1.429 variant of 12 McCallum, M. et al. SARS-CoV-2 immune evasion

13 FACT SHEET FOR HEALTH CARE PROVIDERS: EMERGENCY USE AUTHORIZATION (EUA) OF BAMLANIVIMAB AND ETESEVIMAB,

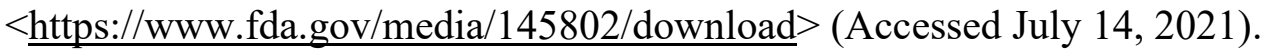

468 humoral immunity and persistent SARS-CoV-2 infection: A consecutive case series. EBioMedicine 67, 103355, doi:10.1016/j.ebiom.2021.103355 (2021).

5 Choi, B. et al. Persistence and Evolution of SARS-CoV-2 in an Immunocompromised Host. N Engl J Med 383, 2291-2293, doi:10.1056/NEJMc2031364 (2020).

6 McCarthy, K. R. et al. Recurrent deletions in the SARS-CoV-2 spike glycoprotein drive antibody escape. Science 371, 1139-1142, doi:10.1126/science.abf6950 (2021).

17 Luan, B., Wang, H. \& Huynh, T. Enhanced binding of the N501Y-mutated SARS-CoV-2 spike protein to the human ACE2 receptor: insights from molecular dynamics simulations. FEBS Lett 595, 1454-1461, doi:10.1002/1873-3468.14076 (2021). 
medRxiv preprint doi: https://doi.org/10.1101/2021.09.03.21263105; this version posted September 15, 2021. The copyright holder for this preprint (which was not certified by peer review) is the author/funder, who has granted medRxiv a license to display the preprint in perpetuity. All rights reserved. No reuse allowed without permission.

47218 Gupta, R. K. Will SARS-CoV-2 variants of concern affect the promise of vaccines? Nat

Rev Immunol 21, 340-341, doi:10.1038/s41577-021-00556-5 (2021).

Chew, K. W. et al. in Conference on Retroviruses and Opportunistic Infections (Virtual, March 6-10, 2021 (Abstract 396)).

20 Ko, S. H. et al. High-throughput, single-copy sequencing reveals SARS-CoV-2 spike variants coincident with mounting humoral immunity during acute COVID-19. PLoS Pathog 17, e1009431, doi:10.1371/journal.ppat.1009431 (2021).

21 Choudhary, M. C., Crain, C. R., Qiu, X., Hanage, W. \& Li, J. Z. SARS-CoV-2 Sequence Characteristics of COVID-19 Persistence and Reinfection. Clin Infect Dis, doi:10.1093/cid/ciab380 (2021).

22 He, X. et al. Temporal dynamics in viral shedding and transmissibility of COVID-19. Nat Med, doi:10.1038/s41591-020-0869-5 (2020).

48423 Weinreich, D. M. et al. REGN-COV2, a Neutralizing Antibody Cocktail, in Outpatients with Covid-19. $N$ Engl J Med 384, 238-251, doi:10.1056/NEJMoa2035002 (2021).

24 Wolfel, R. et al. Virological assessment of hospitalized patients with COVID-2019. Nature, doi:10.1038/s41586-020-2196-x (2020).

25 Pelegrin, M., Naranjo-Gomez, M. \& Piechaczyk, M. Antiviral Monoclonal Antibodies: Can They Be More Than Simple Neutralizing Agents? Trends Microbiol 23, 653-665, doi:10.1016/j.tim.2015.07.005 (2015).

27 Collier, D. A. et al. Sensitivity of SARS-CoV-2 B.1.1.7 to mRNA vaccine-elicited antibodies. Nature 593, 136-141, doi:10.1038/s41586-021-03412-7 (2021).

Zhou, Y. et al. Enhancement versus neutralization by SARS-CoV-2 antibodies from a convalescent donor associates with distinct epitopes on the RBD. Cell Rep 34, 108699, doi:10.1016/j.celrep.2021.108699 (2021). Campbell, F. et al. Increased transmissibility and global spread of SARS-CoV-2 variants of concern as at June 2021. Euro Surveill 26, doi:10.2807/15607917.ES.2021.26.24.2100509 (2021). (2021).

30 Degli-Angeli, E. et al. Validation and verification of the Abbott RealTime SARS-CoV-2 assay analytical and clinical performance. $J$ Clin Virol 129, 104474, doi:10.1016/j.jcv.2020.104474 (2020). 143, 104945, doi:10.1016/j.jcv.2021.104945 (2021).

32 Fajnzylber, J. et al. SARS-CoV-2 viral load is associated with increased disease severity and mortality. Nat Commun 11, 5493, doi:10.1038/s41467-020-19057-5 (2020).

33 Lee, E. R. et al. Performance comparison of next generation sequencing analysis pipelines for HIV-1 drug resistance testing. Sci Rep 10, 1634, doi:10.1038/s41598-020-58544-Z (2020). 
medRxiv preprint doi: https://doi.org/10.1101/2021.09.03.21263105; this version posted September 15, 2021. The copyright holder for this preprint (which was not certified by peer review) is the author/funder, who has granted medRxiv a license to display the preprint in perpetuity.

All rights reserved. No reuse allowed without permission.

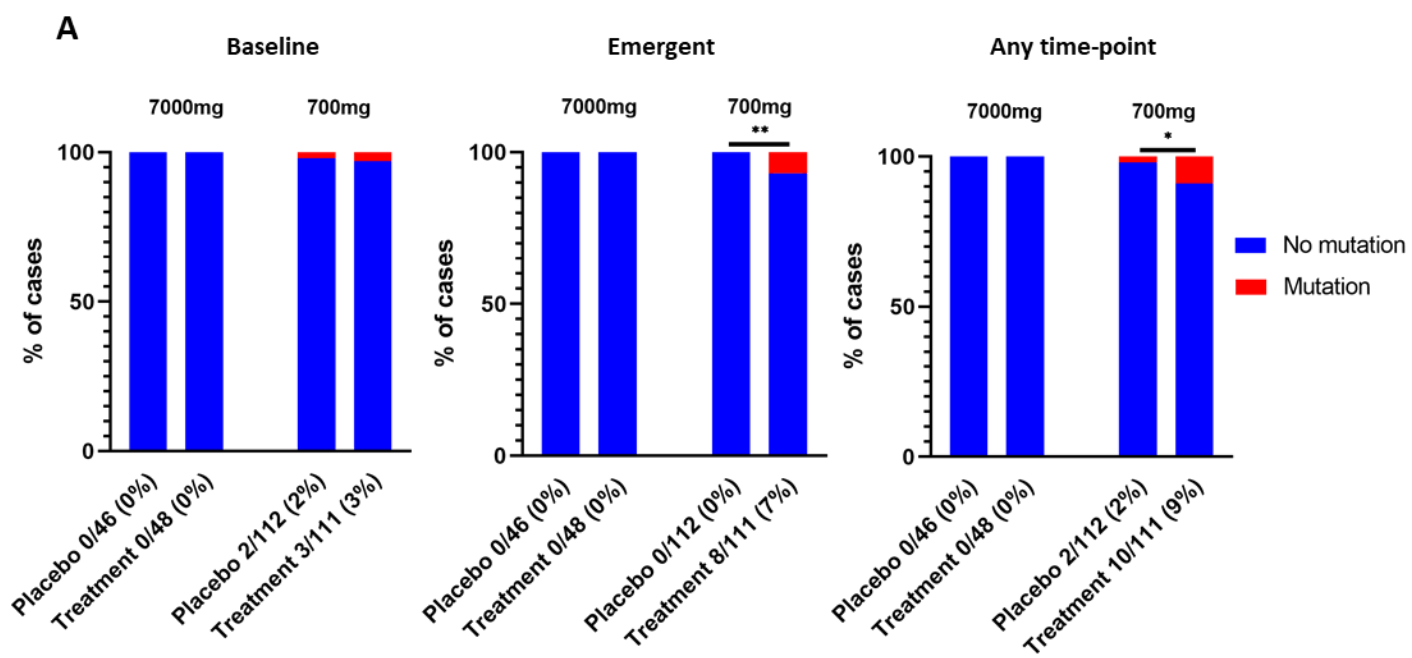

B

Baseline resistance mutations $(n=3)$

Emerging resistance mutations $(n=8)$

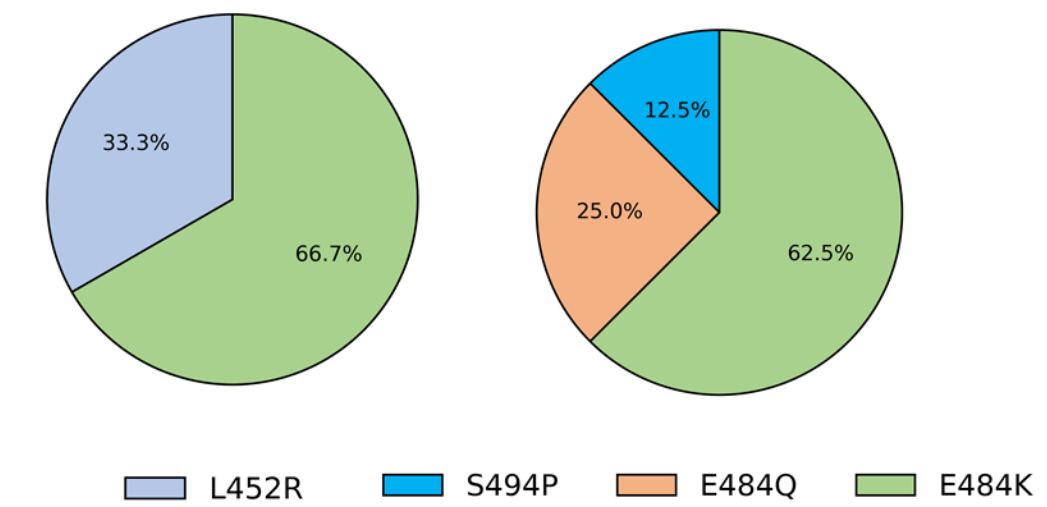

Figure 1: Prevalence of SARS-CoV-2 primary resistance mutations. (A) Percent of participants harboring primary resistance mutations L452R, E484K, E484Q, F490s and S494P at $\geq 20 \%$ frequency in the bamlanivimab $7000 \mathrm{mg}$ and $700 \mathrm{mg}$ treatment and placebo arms at baseline, emergent and at any time-point. Participants without quantifiable viral load at baseline and/or follow-up time points were grouped with those without resistance. P-values were calculated using Fisher's exact test. * $\mathrm{P}<0.05, * * \mathrm{P}<0.01$. (B) Pie-charts showing distribution of baseline and emergent resistance mutations in treatment arm. One participant had E484K at baseline with emerging E484Q mutation. 
A

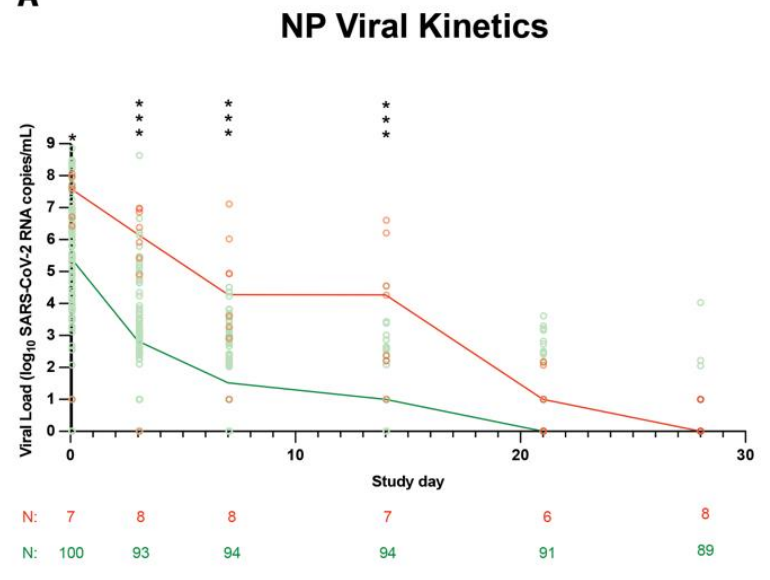

B

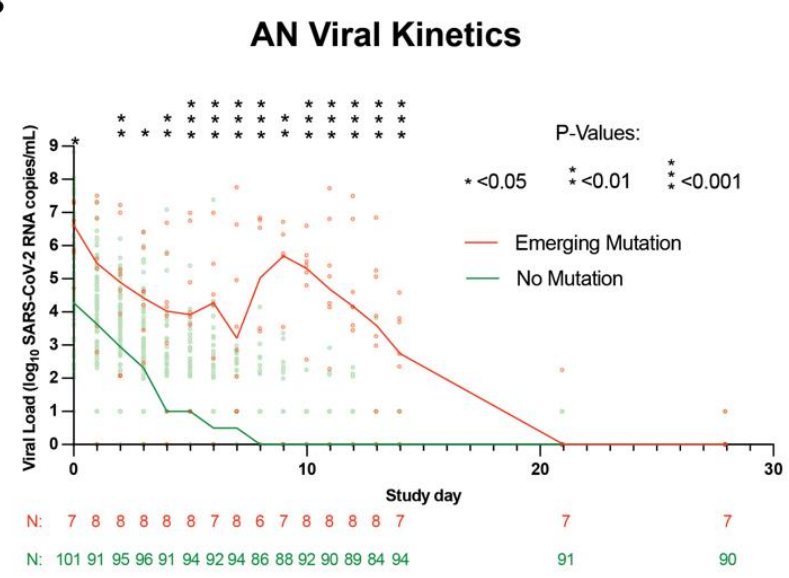

Figure 2: SARS-CoV-2 viral kinetics in the bamlanivimab 700mg treatment arm. SARSCoV-2 viral loads from (A) Nasopharyngeal (NP) swabs (collected at day 0, 3, 7, 14, 21 and day 28) and (B) from anterior nasal (AN) swabs (collected daily through day 14 followed by day 21 and day 28) plotted against study day. Lines show median viral load. Viral loads between groups were compared at each time point using the Mann-Whitney U tests denoted by asterisks wherever significant. The lower limit of quantification was $2.0 \log _{10} \mathrm{SARS}-\mathrm{CoV}-2 \mathrm{RNA}$ copies/mL while the lower limit of detection was $1.0 \log _{10}$ copies $/ \mathrm{mL}$. 
medRxiv preprint doi: https://doi.org/10.1101/2021.09.03.21263105; this version posted September 15, 2021. The copyright holder for this preprint (which was not certified by peer review) is the author/funder, who has granted medRxiv a license to display the preprint in perpetuity.

All rights reserved. No reuse allowed without permission.

a
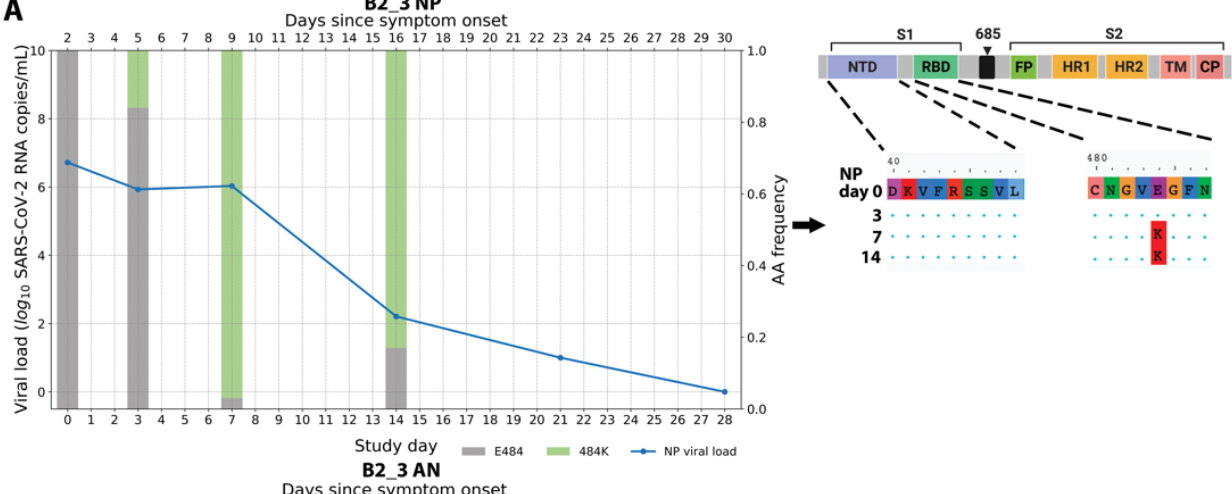

day 0 D

C N G V E G F
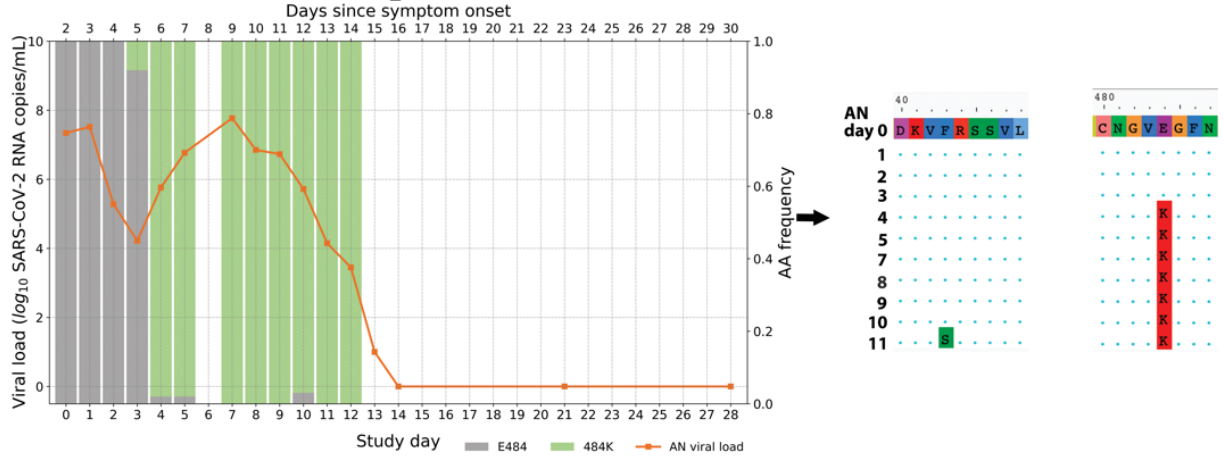

B

B2_2 NP
B Days since symptom onset

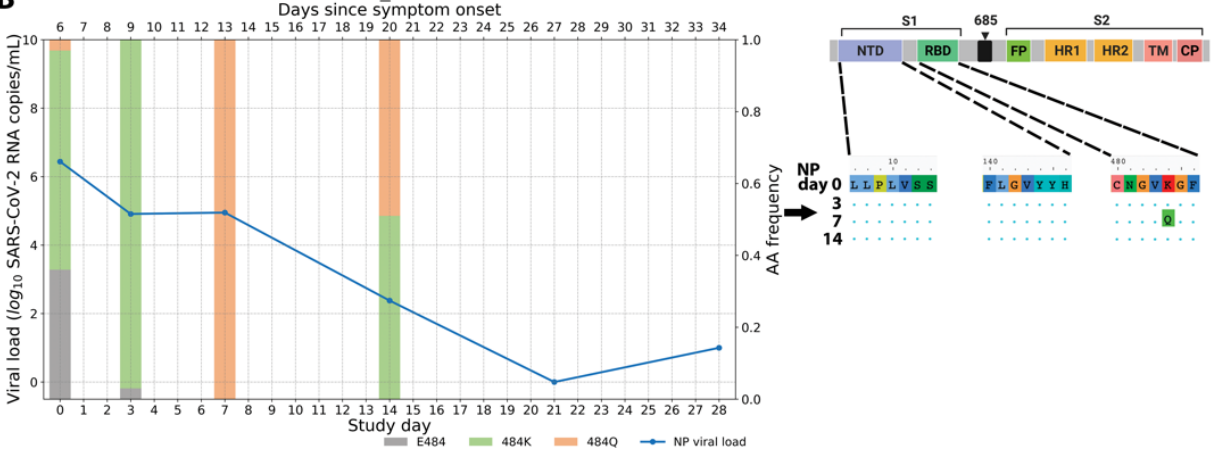

B2_2 AN
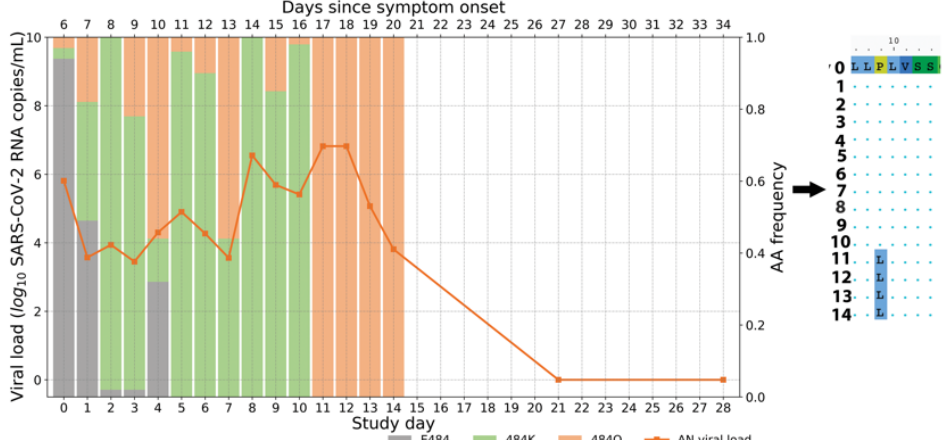

FL GVXX目

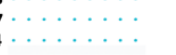

$\ldots$ 
medRxiv preprint doi: https://doi.org/10.1101/2021.09.03.21263105; this version posted September 15, 2021. The copyright holder for this

preprint (which was not certified by peer review) is the author/funder, who has granted medRxiv a license to display the preprint in perpetuity.

All rights reserved. No reuse allowed without permission.

Figure 3: Evidence of viral rebound and/or slow viral decay coupled with dynamic viral population shift and potential compartmentalization. Viral RNA from nasopharyngeal (NP) swabs and anterior nasal (AN) swabs were sequenced and results from two example participants from the bamlanivimab 700mg treated group are shown. (A) Participant B2_3 showed emergence of E484K and viral rebound between study days 3 and 7. (B) Participant B2_2 showed emergence of a mixed population of E484K and E484Q viruses along with multiple rebounds and slow viral decay. Alignments of consensus sequences from both compartments show position of primary escape and other consensus-level mutations at each time point. CP denotes cytoplasmic domain, FP fusion peptide, HR1 heptad repeat 1, HR2 heptad repeat 2, NTD N-terminal domain, RBD receptor binding domain, $\mathrm{S} 1$ subunit 1, S2 subunit 2, and TM transmembrane domain. 
medRxiv preprint doi: https://doi.org/10.1101/2021.09.03.21263105; this version posted September 15,2021 . The copyright holder for this preprint (which was not certified by peer review) is the author/funder, who has granted medRxiv a license to display the preprint in perpetuity.

All rights reserved. No reuse allowed without permission.

A

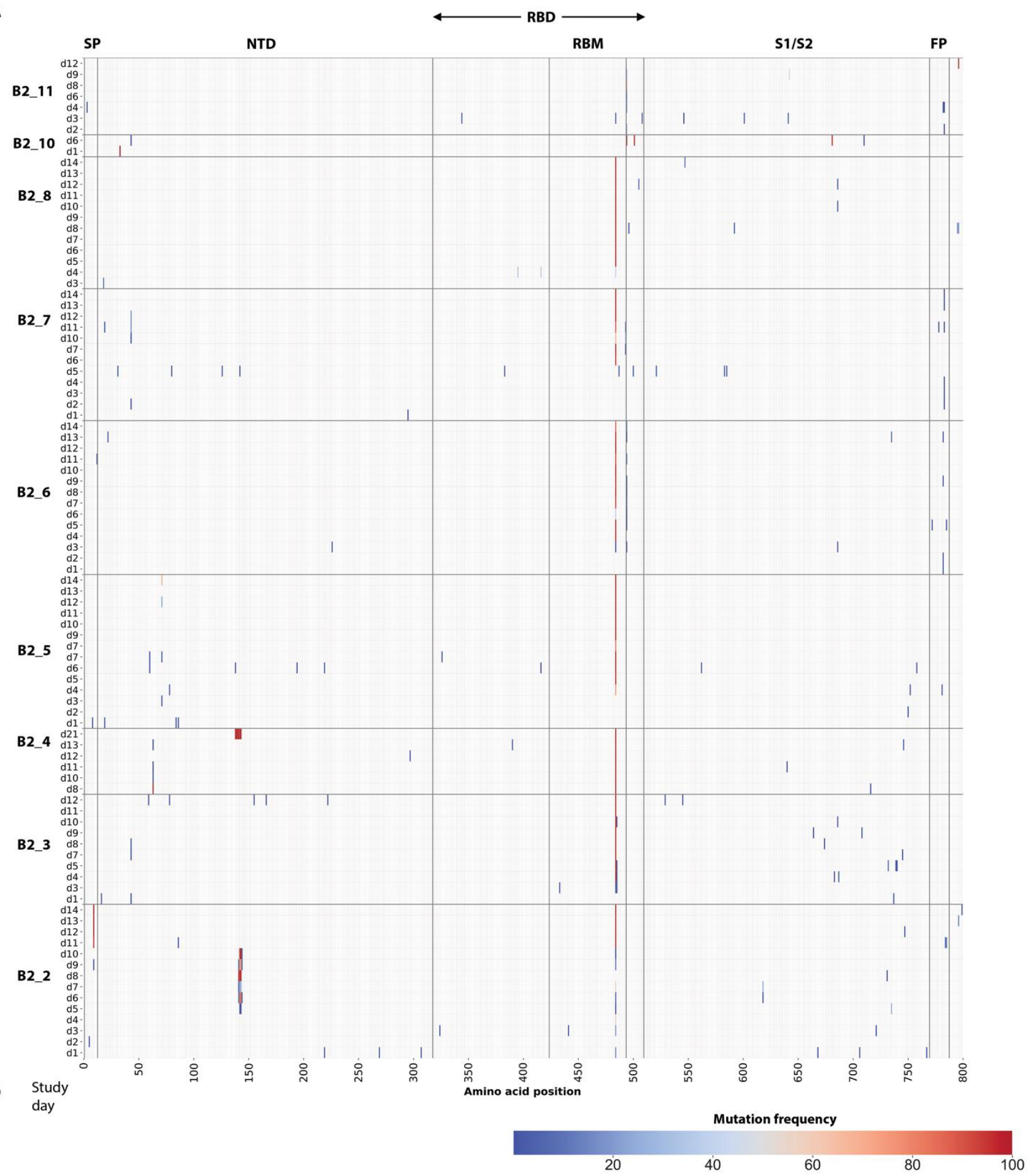


medRxiv preprint doi: https://doi.org/10.1101/2021.09.03.21263105; this version posted September 15, 2021. The copyright holder for this preprint (which was not certified by peer review) is the author/funder, who has granted medRxiv a license to display the preprint in perpetuity.

B

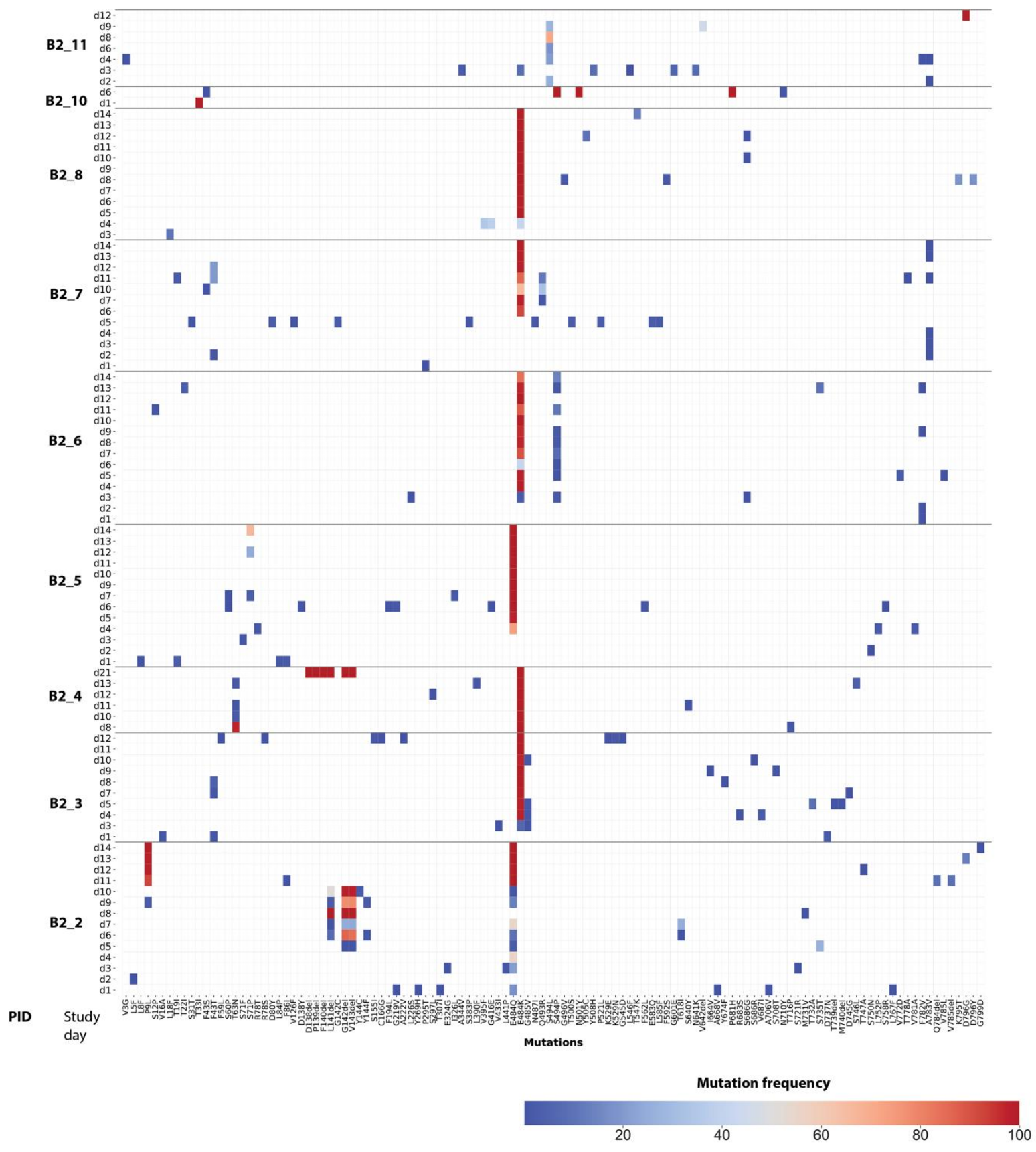

Figure 4: Heat map showing distribution of Spike polymorphisms from AN swab samples in bamlanivimab 700mg treated participants with emerging primary resistance mutations. (A) Panel A shows polymorphism in context of near-full length Spike gene. Y-axis shows participants' ID followed by day of sample collection, while x-axis shows amino-acid positions in Spike gene. Different domains of Spike are shown at the top while color indicates frequency of polymorphisms starting with blue indicating lowest value while red indicates highest value in the scale. (B) Zoomed-in heat-map showing sites which harbors polymorphisms at least one of the samples across different participants. The order of samples is same that in panel A while $\mathrm{x}$-axis denotes 
medRxiv preprint doi: https://doi.org/10.1101/2021.09.03.21263105; this version posted September 15, 2021. The copyright holder for this preprint (which was not certified by peer review) is the author/funder, who has granted medRxiv a license to display the preprint in perpetuity. All rights reserved. No reuse allowed without permission.

amino-acid sites with number indicating position of amino-acids while letter before and after the numbers indicate wild-type and polymorphic amino-acid respectively. SP denotes signal peptide, NTD N-terminal domain, RBD receptor binding domain, RBM Receptor binding domain, S1 subunit 1, S2 subunit 2, and FP fusion peptide. 
medRxiv preprint doi: https://doi.org/10.1101/2021.09.03.21263105; this version posted September 15, 2021. The copyright holder for this preprint (which was not certified by peer review) is the author/funder, who has granted medRxiv a license to display the preprint in perpetuity.

A

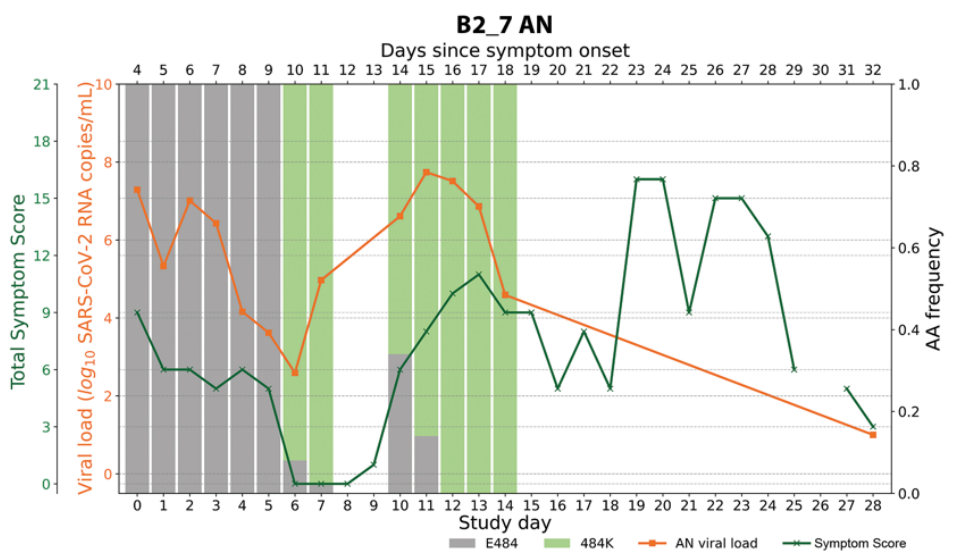

Resistance Emergence

B
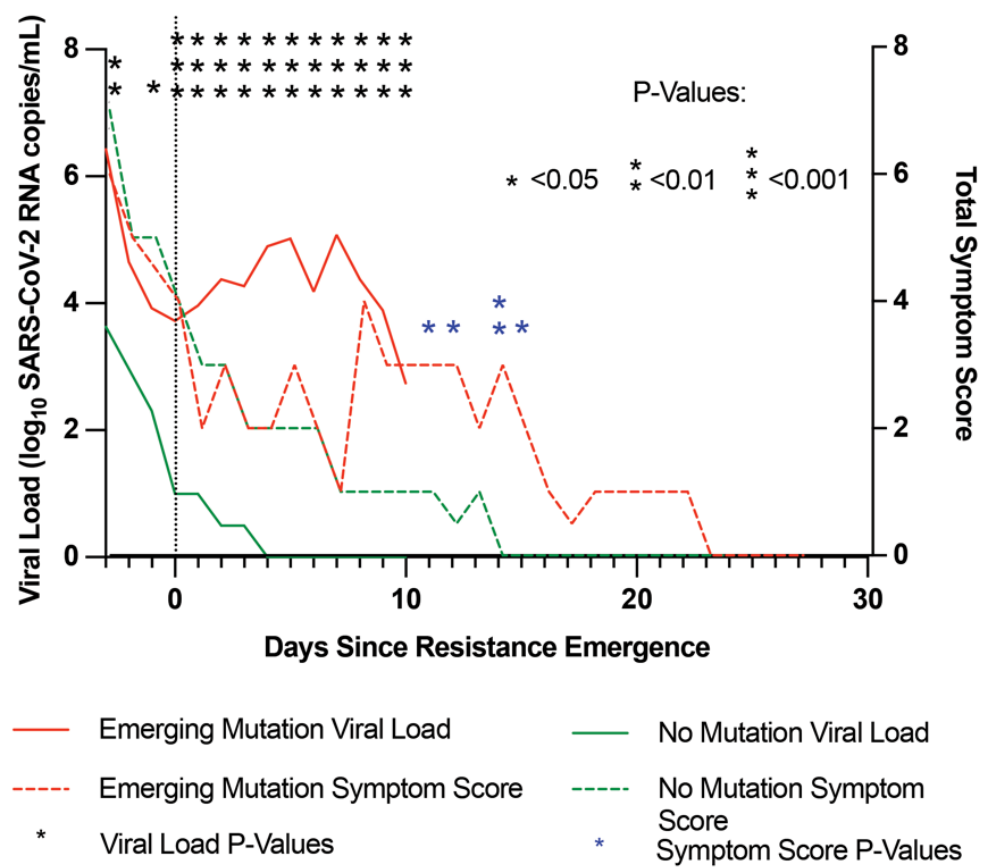

Figure 5. Worsened COVID-19 symptoms with viral resurgence after emergence of resistance mutations. (A) Example of increased anterior nasal (AN) viral load and total symptom score trend for one participant, B2_7, with emerging E484K resistance after bamlanivimab 700mg treatment. (B) Median AN viral load (solid line) and total symptom score (dashed line) plotted from the time of resistance emergence to $\geq 20 \%$ of the viral population (day 0 ) for participants in the bamlanivimab 700mg treatment group with (red) and without (green) emerging resistance mutations. For participants without emerging resistance, day 0 was equivalent to study day 4 , which represented the median day of resistance emergence for those with emerging resistance. 
medRxiv preprint doi: https://doi.org/10.1101/2021.09.03.21263105; this version posted September 15, 2021. The copyright holder for this preprint (which was not certified by peer review) is the author/funder, who has granted medRxiv a license to display the preprint in perpetuity. All rights reserved. No reuse allowed without permission.

Symptom score between the emerging resistance and no emerging resistance groups is compared at each day by Mann Whitney $\mathrm{U}$ tests. $* \mathrm{P}<0.05, * * \mathrm{P}<0.01$. 
medRxiv preprint doi: https://doi.org/10.1101/2021.09.03.21263105; this version posted September 15, 2021. The copyright holder for this preprint (which was not certified by peer review) is the author/funder, who has granted medRxiv a license to display the preprint in perpetuity.

All rights reserved. No reuse allowed without permission.

Table 1: Demographic characteristics of enrolled participants receiving bamlanivimab treatment comparing those with emerging resistance to those without any detected resistance mutations. One participant had both baseline and emerging resistance and was included in the Emerging resistance category. Statistical analysis was performed using Mann Whitney $U$ tests for continuous variables and Fisher's exact tests for discrete variables.

\begin{tabular}{|c|c|c|c|c|}
\hline Characteristic & $\begin{array}{l}7000 \text { mg Treatment } w / \\
\text { Bamlanivimab } \\
(\mathrm{N}=48)\end{array}$ & $\begin{array}{c}700 \text { mg Treatment w/ } \\
\text { Bamlanivimab } \\
\text { (No resistance) } \\
(\mathrm{N}=\mathbf{1 0 1})\end{array}$ & $\begin{array}{l}700 \text { mg Treatment w/ } \\
\text { Bamlanivimab } \\
\text { (Emerging } \\
\text { resistance) } \\
(\mathbf{N}=\mathbf{8})\end{array}$ & $\begin{array}{c}\text { P-Value } \\
\text { (Comparison } \\
\text { between those } \\
\text { with and } \\
\text { without } \\
\text { resistance) }\end{array}$ \\
\hline Age, median years [Q1,Q3] & $46[33,58]$ & $45[34,54]$ & $56[50,64]$ & 0.01 \\
\hline Female sex, $\%$ & 54 & 50 & 50 & 1.0 \\
\hline \multicolumn{5}{|l|}{ Race/Ethnicity, \% } \\
\hline White & 56 & 85 & 75 & 0.61 \\
\hline Black & 6 & 10 & 25 & 0.21 \\
\hline Hispanic & 31 & 17 & 13 & 1.0 \\
\hline Other & 6 & 5 & 0 & 1.0 \\
\hline BMI, median score [Q1,Q3] & $28.2[24.8,31.8]$ & $28.2[25.1,33.7]$ & $29.4[26.4,38.2]$ & 0.36 \\
\hline $\begin{array}{c}\text { Baseline NP VL, median } \\
\log _{10} \text { SARS-CoV-2 } \\
\text { copies/mL [Q1, Q3] }\end{array}$ & $5.2[2.4,6.6]$ & $5.5[3.9,6.8]$ & $7.6[6.4,8.0]$ & 0.04 \\
\hline $\begin{array}{c}\text { Baseline AN VL, median } \\
\log _{10} \text { SARS-CoV-2 } \\
\text { copies/mL [Q1, Q3] }\end{array}$ & $4.1[1.0,5.9]$ & $4.3[2.3,6.1]$ & $6.6[5.8,7.3]$ & 0.02 \\
\hline $\begin{array}{l}\text { Days from symptom onset to } \\
\text { randomization, median days } \\
{[\mathrm{Q} 1, \mathrm{Q} 3]}\end{array}$ & $6.0[4.0,8.0]$ & $6.0[5.0,8.0]$ & $4.5[2.5,7.5]$ & 0.15 \\
\hline
\end{tabular}

